УДК 33(061.1€С):502.171

Скороход Ірина, кандидат економічних наук, доцент, Східноєвропейський національний університет імені Лесі Українки, кафедра міжнародних економічних відносин та управління проектами, м. Луцьк; ORCID ID: 0000-0001-8628-3715, e-mail: skorokhodiryna1@gmail.com

Войчук Максим, кандидат економічних наук, докторант, Східносвропейський національний університет імені Лесі Українки, кафедра міжнародних економічних відносин та управління проектами, м. Луцьк; ORCID ID: 0000-0002-3848-9708, e-mail: voichukmaxym@gmail.com

https://doi.org/10.29038/2411-4014-2020-02-25-32

\title{
ОСОБЛИВОСТІ ФОРМУВАННЯ ТА РОЗВИТКУ СПІЛЬНОГО ЕКОЛОГІЧНОГО РИНКУ СС
}

У статті розглянуто особливості формування та розвитку спільного екологічного ринку в країнах ЄС. Визначено поняття спільного екологічного ринку та еко-індустрії . Охарактеризовано основні передумови формування спільного екологічного ринку СС, серед яких виділено фіскальні обмеження та заборони на виготовлення продукції, що містить шкідливі речовини; формування Єврокомісією програм сертифікації та екологічного маркування; збільшення попиту на екологічно чисту продукцію та послуги. Проаналізовано структуру секторів спільного екологічного ринку СС. Визначено основні тенденції формування й розвитку спільного екологічного ринку СС. Акцентовано увагу на стрімкому зростанні темпів розвитку екологічного ринку, що, в свою чергу зробить екологічну галузь перспективною в майбутньому.

Ключові слова: спільний екологічний ринок, еко-індустрія, органічна продукція, екологічні послуги, Свропейський Союз.

Скороход Ирина, кандидат экономических наук, доцент,

Восточноевропейский национальный университет имени Леси Украинки, кафедра международных экономических отношений и управления проектами, г. Луцк

Войчук Максим, кандидат экономических наук, докторант, Восточноевропейский национальный университет имени Леси Украинки, кафедра международных экономических отношений и управления проектами, г. Луцк

\section{ОСОБЕННОСТИ ФОРМИРОВАНИЯ И РАЗВИТИЯ ОБЩЕГО ЭКОЛОГИЧЕСКОГО РЫНКА ЕС}

В статье рассмотрены особенности формирования и развития общего экологического рынка в странах ЕС. Определено понятие общего экологического рынка и эко-индустрии. Охарактеризованы основные предпосылки формирования общего экологического рынка ЕС, среди которых выделено фискальные ограничения и запреты на изготовление продукции, содержащей вредные вещества; формирование Еврокомиссией программ сертификации и экологической маркировки; увеличение спроса на экологически чистую продукцию и услуги. Проанализирована структура секторов общего экологического рынка ЕС. Определены основные тенденции формирования и развития общего экологического рынка ЕС. Акцентировано внимание на стремительном росте темпов развития экологического рынка, что, в свою очередь сделает экологическую отрасль перспективной в будущем. 
Ключевые слова: общий экологический рынок, эко-индустрия, органическая продукция, экологические услуги, Европейський Союз.

\section{Iryna Skorokhod, PhD in Economics, Associate Professor, Lesya Ukrainka Eastern European National University, Department of International Economic Relations and Project Management,} Lutsk

Maksym Voichuk, PhD in Economics, Postdoctoral, Lesya Ukrainka Eastern European National University, Department of International Economic Relations and Project Management, Lutsk

\section{PECULIARITIES OF THE EU SINGLE ENVIRONMENTAL MARKET FORMATION AND DEVELOPMENT}

The development of the environmental market is a global trend, which is particularly dynamic in the EU. European countries have shown a significant role for the environmental goods and services sector in ensuring their economic growth. Today, in the area of integration, this sector is dynamically developing as environmental demands of consumers for the products and environmental quality in general have increased. The processes of investing in energy efficiency improvement, development and implementation of eco-friendly technologies and waste management have significantly intensified. Therefore, priority is given to the development of EU single environmental market.

The purpose of the article is to study the features of forming a single environmental market in the countries of the European Union and to identify current trends of it development.

The authors determine that the environmental market and the market of ecological goods and services are practically identical categories, and the eco-industry is a component and basis of formation and development. The article describes the basic prerequisites for the creation of EU single environmental market, among which fiscal restrictions and prohibitions on the manufacture of products containing harmful substances are highlighted; formation of certification and eco-labeling programs by the European Commission; increasing demand for environmentally friendly products and services, driven by a worldwide trend towards environmental conservation and health.

The structure of the EU single environmental market sectors is analyzed. The article emphasizes that one of the defining features of the development of the EU organic produce market is the constant increase in demand and price increases of $20-50 \%$ compared to the traditional market.

The EU single environmental market is one of the most developed in the world. The rapid growth of its development is expected, which in turn will make the ecological industry promising in the future. The main trends in the development of the EU single environmental market are: an increase in the production of organic products and the provision of services according to market needs; increase in the number of employees in the field of eco-industry. Increasing public awareness of how lifestyle and consumer choices affect the environment, which in turn has led to increased demand for eco-friendly products and services.

Keywords: single ecological market, eco-industry, organic products, environmental services, European Union.

Постановка проблеми та ї̈ значення. Важливою передумовою структурних зрушень економіки є розвиток еко-індустрії. Європейські країни показали значну роль сектору екологічних товарів та послуг в забезпеченні їхнього економічного зростання. Сьогодні на території інтеграційного об’єднання цей сектор динамічно розвивається, оскільки підвищились екологічні вимоги споживачів до виробленої продукції та якості довкілля загалом. Значно активізувались процеси інвестування у підвищення енергоефективності, розвиток і впровадження екобезпечних технологій та управління відходами.

Тому пріоритетності набуває розвиток спільного екологічного ринку в Свропейському Союзі.

Аналіз останніх досліджень і публікацій. Питанням формування та розвитку екологічного ринку присвячена значна кількість наукових праць вітчизняних та зарубіжних вчених. Так, зарубіжними дослідниками в цій сфері є Дж. Блатер, Дж. Бішоп, Б. Гіллеспі, Г. Дейлі, М. Коммон, Р. Костанза, А. Лопез, П. Ніджкемп, У. Е. Оутс, Д. Пірс, А. Рендолл, К. Тізделл, Б. Філд та ін., ними розроблено теоретичні засади екологічного ринку, еко-індустрії та екологічної модернізації. Серед вітчизняних вчених, які досліжували питання щодо формування екологічного ринку, слід виділити Т. 
Вайданича, О. Веклич, А. Вічевича, І. Дідовича, А. Дідович, С. Ілляшенка, Н. Котенко, Ю. Навроцького, Н. Потапенко, О. Прокопенко, О.Фомичевої, В. Шевчука та ін. В їх наукових працях розкрито економічну значущість екологічного ринку, визначено та подано оцінку обсягу даного ринку, обгрунтовано доцільність розвитку екологічного ринку в Україні. У той же час деякі питання щодо формування та розвитку спільного європейського екологічного ринку потребують подальшого дослідження.

Мета і завдання статті. Метою статті є дослідження особливостей формування та розвитку спільного екологічного ринку в країнах Європейського Союзу. Для досягнення поставленої мети необхідно вирішити такі завдання: дослідити сутність та структуру спільного екологічного ринку ЄC; охарактеризувати нормативно-правову базу та передумови розвитку спільного екологічного ринку в Свропейському Союзі; проаналізувати структуру секторів спільного екологічного ринку СС; визначити сучасні тенденції формування й розвитку спільного екологічного ринку ЄС.

Викладення основного матеріалу та обгрунтування отриманих результатів дослідження. Впровадження концепції чистого виробництва формує основу розвитку екологічного підприємництва. Запровадження даного принципу в економічній системі, 3 одного боку, трансформує та переорієнтовує наявні підприємства, а з другого - створює умови для формування нових сегментів підприємницької діяльності.

В сучасні науковій літературі існує ряд визначень, для позначення цього сегменту, що утворюється в результаті переорієнтації виробників, зокрема, екологічний ринок, ринок екологобезпечних товарів та послуг, еко-індустрія [1].

Попри ототожнення даних понять, існує відмінність у їх сутнісному та змістовному наповненні. Так, якщо екологічний ринок та ринок екологічних товарів і послуг є практично ідентичними категоріями, то еко-індустрія $є$ його складовою та основою формування і розвитку.

Екологічний ринок - визначають як складову загального ринкового середовища, яка характеризується конкурентним обміном усім тим, що спрямоване на збереження, відновлення і раціональне використання навколишнього природного середовища, поліпшення якості життя людей та їхнього екологічного убезпечення. Екологічний ринок - це ринок екологічних технологій, робіт, промислових товарів, послуг, знань, екологічної інформації [2].

Відповідно до цього визначення можна говорити про виокремлення окремої підсистеми ринкових відносин, чий розвиток визначається внутрішніми тенденціями еко-індустрії. Особливе місце в структурі екологічного ринку займає ринкова інфраструктура, що представлена особливим типом підприємств - екологічно орієнтованими підприємствами. Крім того, специфіка даного ринку визначається рядом міжнародних нормативно-правових документів та на ії розвиток має вплив діяльність наднаціональних та міжнародних організацій.

Щодо визначення категорії «спільний ринок», то в Постанові Суду ЄС № 15/81 від 5 травня 1982 року зазначено, що «спільний ринок - це етап економічної інтеграції, спрямований на скасування всіх торговельних перешкод у межах Спільноти з метою об'єднання національних ринків у єдиний ринок, створюючи таким чином умови, якнайбільше наближені до справжнього внутрішнього ринку» [3].

Створення спільного ринку, потребувало не тільки поглиблення торговельних відносин між державами-учасницями процесу, для цього також був необхідним вільний рух факторів виробництва - праці, послуг і капіталу [4]. Так чи інакше, формування спільного ринку першочергово передбачало ліквідацію бар'єрів у торгівлі, русі капіталу та громадян.

У формуванні та розвитку спільного екологічного ринку ЄС важливу роль відіграє екоіндустрія. Одним зі способів визначення еко-індустрії $є$ включення товарів та послуг, які забезпечують охорону навколишнього природного середовища, в різні сфери: вода, тверді відходи, повітря, грунт, шум, природних ресурси, неоднорідні послуги і т.д. Тому еко-індустрію за сферами використання умовно можна поділити на сферу виробництва екологічного обладнання та сферу надання екологічних послуг (рис. 1.).

Продукція еко-індустрії реалізується на ринку, формуючи в такий спосіб пропозицію на ньому. У формуванні попиту на продукцію екоіндустрії беруть участь усі традиційні економічні суб'єкти фінансові та нефінансові підприємства, держава, іноземні резиденти, домашні господарства. Ці суб'єкти взаємодіють на екологічному ринку екологобезпечних товарів та послуг зі своїми 
контрагентами - виробниками, представниками еко-індустрії, в межах інформаційно-кон'юктурного поля [6, с.137].

Еко-індустрія - це категорія, що охоплює широкий спектр діяльності, пов'язаної 3 вимірюванням, попередженням або мінімізацією, і корекцією екологічних збитків. Вона включає товари та послуги від обладнання та послуг зі зменшення забруднення й утилізації відходів, до діяльності з розробки і імплементації нових технологій. На відміну від традиційних секторів, які можуть бути легко визначені за допомогою одного або декількох показників в класифікації NACE (European Classification of Economic Activities), екоіндустрія є категорією гібридного типу, через те, що вона охоплює різні підсектори NACE, часто в 4- або 5-значного рівня [7].

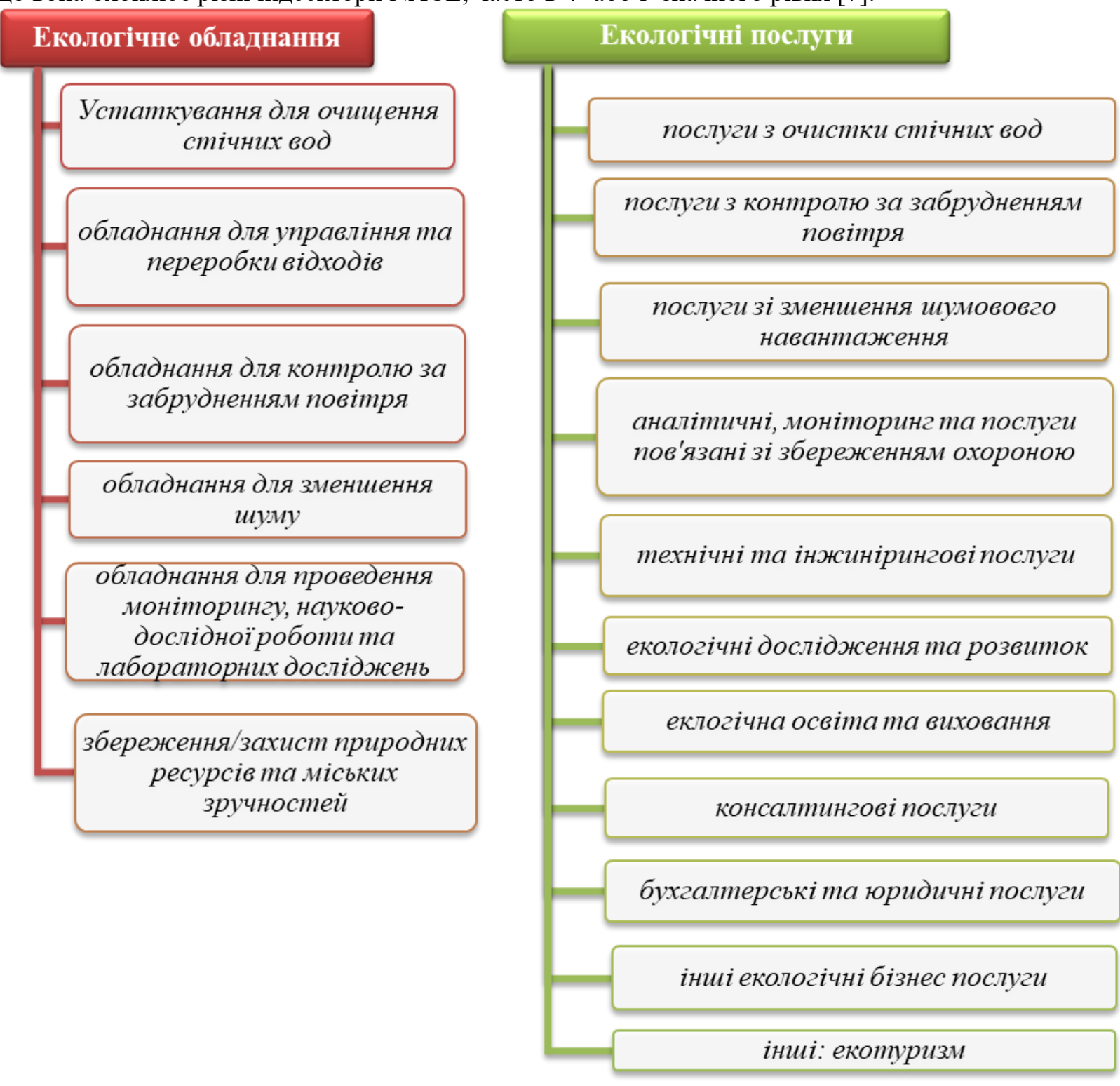

Рис. 1. Класифікачія складових екоіндустрії за сферами

Джерело: побудовано автором за даними [5]

Еко-індустрія не має чіткого статистичного статусу і не є частиною традиційної галузевої системи. Протягом довгого часу еко-індустрія визначалась як сума виробників технологій кінцевого виробничого циклу, як правило, додаючи заходи з очищення брудних технологій (включаючи супутні послуги). Тим часом еко-індустрія визначається двома різними функціями: 
1. Управління відходами: сектори, які управляють матеріальними потоками 3 процесів техносфери до природи, зазвичай з використанням технологій «кінцевого виробничого циклу».

2. Ресурсний менеджмент: сектори, які використовують більш превентивний підхід до управління матеріальними потоками від природи до техносфери [8].

У ряді досліджень було здійснено спробу визначення, розмежування та опису еко-індустрії, проте досі не існує єдиного підходу. Існує кілька підстав для виникнення суперечностей при розгляді даного питання. По-перше, дана галузь охоплює різнорідний набір товарів і послуг. В основі промисловості загалом, лежить група ідентифікованих товарів і послуг, які використовуються 3 метою очищення існуючих процесів і виробництва (обладнання «кінцевого виробничого циклу» або технології), очищення води і стоків, контролю забруднення повітря і зниження рівня шумового навантаження. Існує також управління відходами та переробні технології й послуги для відновлення відходів з метою їх повторного використання, які оперують 3 попереднім екологічним збитком, а також зростаюча кількість екологічних послуг, таких як науково-дослідні, проектні та інженерні послуги. Більшість 3 цього устаткування, технологій та послуг, можуть бути визначені й виміряні, але вони $є$ неоднорідними, що робить збір даних складним [5].

По-друге, немає чітко визначених меж. Зокрема, існує зростаючий інтерес щодо включення відновлюваних джерел енергії, екологічно чистих технологій i продуктів. У довгостроковій перспективі, в той час як вони складно піддаються опису, чисті технології, виробничі процеси і продукти знизять потребу в очищенні і обладнанні кінцевого виробничого циклу, змінюючи структуру екологічної промисловості і відносну важливість іiі основної групи складових.

По-трете, багато виробників обладнання та послуг для скорочення і контролю за забрудненням мають низький ступінь спеціалізації в даній сфері. Екологічні товари та послуги можуть бути класифіковані з іншими товарами і послугами, які $є$ основною сферою діяльності, i тому їх не можна легко відокремити для включення до екоіндустрії. Крім того, різні дослідження були зосереджені на більш широкій або більш вузькій групі діяльності або продукції, відповідно отримуючи різні результати, залежно від того чи були вони зосереджені на власне екологічній діяльності, чи екопродукції, загальних статистичних дослідженнях і т.д. Результати дослідження залежать також від того, що було взято за основу - попит чи пропозиція.

Враховуючи екологічну ситуацію у світі, уряди країн $С \mathrm{C}$ приділяють велику увагу безпечності та екологічності продукції. Тому в останні десятиліття особливого значення набуває розробка та впровадження нормативно-правової бази задля контролю над екологічністю продукції.

В СС правове регулювання у сфері виробництва екологічних товарів та послуг здійснюють відповідно до Директиви Ради ЄС № 834/2007 та Директиви Комісії ЄС № 889/2008, що набули чинності з 01.01.2009 року, прийнятими на заміну Директиви Ради ЄЕС № 2092/91. Директива Комісії ЄС № 889/2008 деталізує правила органічного виробництва Директиви Ради ЄС № 834/2007. У преамбулі до Директиви Ради СС № 834/2007 зазначено, що ії прийняття обумовлено зростаючим попитом споживачів на сільськогосподарську та харчову продукцію, одержану із застосуванням методів органічного виробництва [9].

На нашу думку, основними передумовами формування спільного екологічного ринку ЄС стали:

- фіскальні обмеження та заборони на виготовлення продукції, що містить шкідливі речовини, що були поступово описані у шести програмах дій у сфері захисту навколишнього середовища;

- формування Єврокомісією програм сертифікації та ліцензування екологічно чистої продукції, послуг, виробничих процесів, зокрема програма екологічного маркування ecolabel eu;

- збільшення попиту на екологічно чисту продукцію та послуги, який зумовлений світовою тенденцією до збереження навколишнього середовища та охорони здоров'я.

Хоча спільний екологічний ринок ЄС доволі рівномірно розвивається у розрізі регіонів та окремих країн, розподіл ринку за секторами є неоднорідним. Це свідчить про те, що у різних країнах-членах $\mathrm{CC}$ пріоритетними $є$ різні сфери екологічного ринку, залежно від попиту та регіональних особливостей, а також експортоорієнтованості тієї чи іншої країни.

Наприклад, щорічний оборот на ринку переробки сміття в Італії перевищує $40 \%$ від загального показника усього екологічного ринку даної країни. Для порівняння, у Великобитанії та Німеччині він сягає менше $15 \%$, що вважається незначним показником. Проте, на ринок вторинної переробки відходів у Великобританії припадає більше $30 \%$ загального обороту екологічного ринку, що $є$ 
найвищим показником серед країн $Є С$. Для порівняння, середній показник для $Є С$ складає $25 \%$. Також частки третього за величиною сектору екологічного ринку, водопостачання, варіюються залежно від країни [10]. Структуру секторів спільного екологічного ринку СС за 2018 рік наведено на рис. 2.

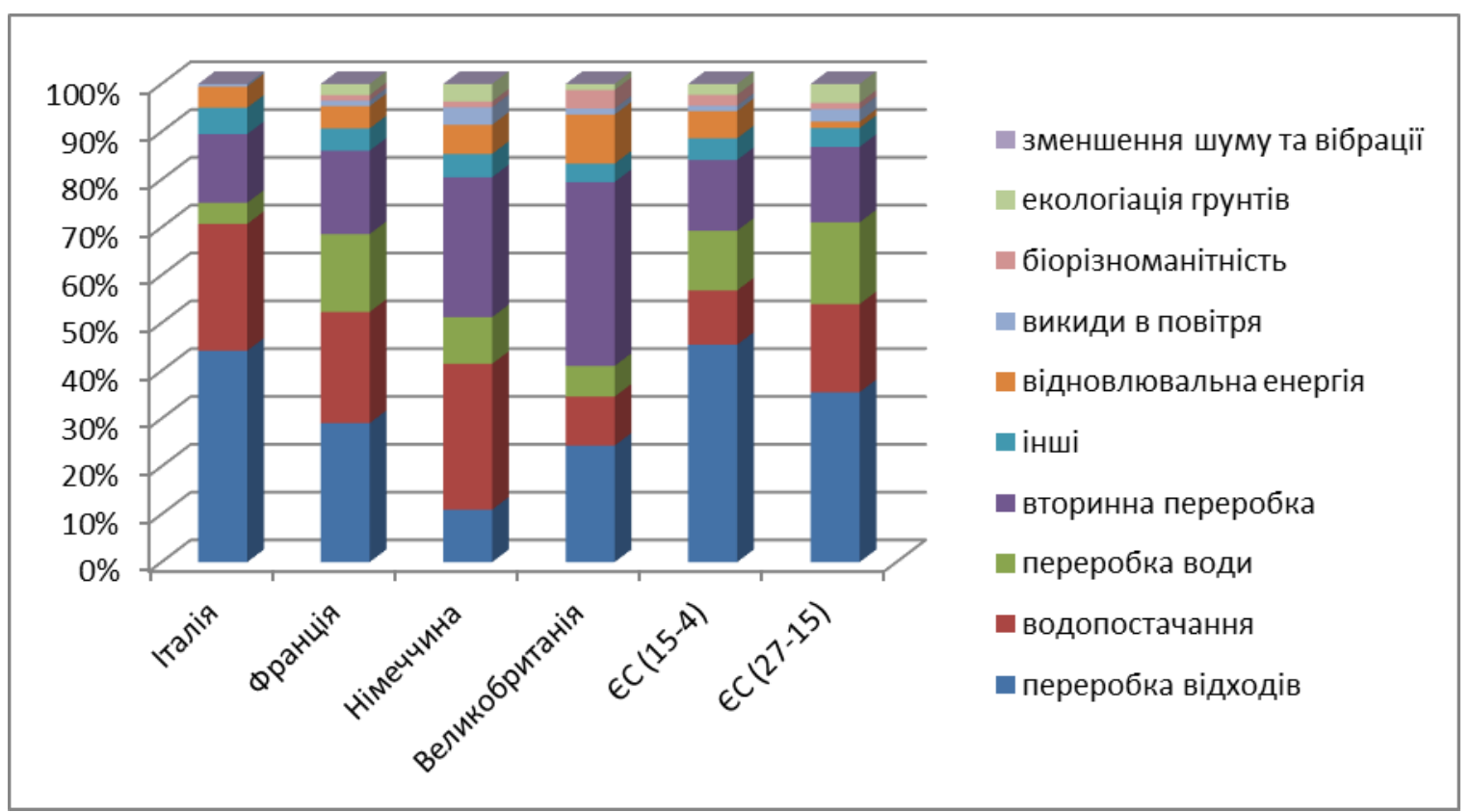

Рис. 2. Структуру секторів спільного екологічного ринку ЄС за 2018 рік

Джерело: побудовано автором за даними [10]

Екологічний ринок створює значну кількість нових робочих місць. У країнах ЄС у секторі екологічних товарів і послуг працює близько 3,4 млн осіб. У Європейському Союзі нараховується майже 310000 виробників екологічних товарів та послуг, а найбільша кількість простежується у Туреччині (понад 75000 ) та Італії (понад 68 000), що в перспективі може вивести ці країни у лідери даної галузі. У 2018 році, порівняно з попереднім роком кількість виробників зросла майже на 4\%. Тенденція до помірного зростання спостерігається уже впродовж десятиліття [11].

Однією з визначальних особливостей розвитку ринку органічної продукції $\epsilon \mathrm{\epsilon} \epsilon$ постійне зростання попиту та збільшення ціни на 20-50\% в порівнянні з традиційним ринком. Так, серед країн Європи, можна виділити таких лідерів за середніми витратами на споживання органічної продукції в розрахунку на душу населення, як Швейцарія (103 євро), Швеція (47 євро), Німеччина (38 євро), Франція та Великобританія (27 євро). Основні європейські канали збуту для органічної продукції це мережа роздрібної торгівлі (70\%), прямі продажі з підприємств і продажі через ринки, які забезпечують приблизно 15\% збуту, продажі через спеціалізовані магазини до $15 \%$. Покупці в середньому переплачують за органічні продукти 40-60\% [12].

Темпи приросту екологічного ринку найвищі у країнах Прибалтики - до $8 \%$ на рік. На цей час головними експортерами на європейському екологічному ринку $\epsilon$ Німеччина, Франція i Великобританія, на які припадає $55 \%$ торгівлі екологічними товарами ЄС. Найбільшими екологічними ринками в ЄС є Франція і Німеччина (49 \% від загального об'єму на 2019 р.). Великобританія, Італія та Голландія формують $24 \%$ загального об'єму, а на 10 нових членів ЄС припадає усього 5,7 \%, з яких половина (2,9\%) належить Польщі [13].

Досліджуючи формування й розвиток спільного екологічного ринку $\mathrm{\epsilon C}$, можна виділити такі тенденції: збільшення обсягів випуску екологічної продукції й надання послуг відповідно до потреб ринку; зростання кількості зайнятих в сфері еко-індустрії; зростання рівня обізнаності населення щодо того, як спосіб життя та споживацький вибір впливають на довкілля, що, в свою чергу, спричинило зростання попиту на екологічно чисті продукти та послуги. 
Висновки і перспективи подальших досліджень. Таким чином, спільний екологічний ринок $Є С$ є одним із найрозвинутіших у світі. Очікується стрімке зростання темпів його розвитку, що, в свою чергу зробить екологічну галузь перспективною в майбутньому. Обсяг пропозиції на екологічному ринку значно перевищує попит, тим самим надаючи можливість для виробників створювати нові продукти та розширювати традиційний збут. Німеччина, Франція і Великобританія $\epsilon$ основними країнами-виробниками органічної продукції, а відповідно й експортерами. Західноєвропейські фірми, що займаються екологічним підприємництвом, успішно використовують сучасні тенденції в природоохоронній політиці для збільшення своїх прибутків.

Перспективами подальших досліджень $є$ оцінка кон'юнктури спільного європейського екологічного ринку. До основних факторів, які впливають на формування попиту й пропозиції на цьому ринку, доцільно віднести розвиток екологічних технологій, виникнення нових ринкових сегментів та підтримка екологічного сектору за допомогою державних закупівель, пільг та інших економічних інструментів.

\section{Джерела та література}

1. Потапенко Н. Особливості формування ринку екологобезпечних товарів, технологій та послуг в Україні. Економіка України. 2001. №4. С. 28-29.

2. Шевчук В. Я., Саталкін Ю. М., Білявський Г. О. Екологічне управління. Київ: Либідь, 2004. 432 с.

3. Judgment of May 5 Gaston Schul., case 15/81, ECR $1982 . \quad$ URL: http://www.competitionlaw.cn/upload/temp_09060910426989.pdf (дата звернення: 25.02.2020).

4. Ніколас Мусис. Усе про спільні політики Європейського Союзу. пер. з англ. Київ: «К.І.С.», 2005. 466 с.

5. OCED Report. The Global environmental goods and services industry. URL: http://www.oecd.org/industry/ind/2090577.pdf (дата звернення: 01.03.2020).

6. Петрушенко Ю. М., Садовий В. О., Тарасенко С. В. Міжнародний досвід формування ринку екологобезпечних товарів та послуг. Механізм регулювання економіки. 2009. №4, Т. 2. С. 136-141.

7. Study on the Competitiveness of the EU eco-industry: Within the Framework Contract of Sectoral Competitiveness Studies - ENTR/06/054. Final Report - Part $1 . \quad$ URL: http://ec.europa.eu/DocsRoom/documents/1459/attachments/1/translations/en/renditions/native (дата звернення: 15.02.2020).

8. Ernest\&Young Report for European Commission. Study on Eco-industry, its size, employment, perspectives and barriers to growth in an enlarged EU Final report, August 2006. URL: http://ec.europa.eu/environment/enveco/eco_industry/pdf/ecoindustry2006.pdf (дата звернення: 22.03.2020).

9. The EU eco-industry in the world. URL: http://ec.europa.eu/environment/enveco (дата звернення: 28.01.2020).

10. Study on the Competitiveness of the EU eco-industry. Brussels, 22 October 2018. Ecorys. 216 p.

11. The environmental goods and services sector - a data collection handbook. - Luxembourg: Office for Official Publications of the European Communities, 2019 - 196 pp.

12. EGSS production, \% of GDP, by type of activity (market, non market, ancillary), latest available year. URL: http://epp.eurostat.ec.europa.eu (дата звернення: 12.03.2020).

13. The World of Organic Agriculture 2019. URL: https://www.organic-world.net/yearbook/yearbook-2019.html (дата звернення: 18.03.2020).

\section{References}

1. Potapenko N. (2001) Osoblyvosti formuvannia rynku ekolohobezpechnykh tovariv, tekhnolohii ta posluh v Ukraini. [Features of formation of the market of environmentally friendly goods, technologies and services in Ukraine]. Ekonomika Ukrainy - Economy of Ukraine. 4, 28-29 [in Ukrainian].

2. Shevchuk V. Ya., Satalkin Yu. M. \& Biliavskyi H. O. (2004) Ekolohichne upravlinnia. [Environmental management]. Kyiv: Lybid, 432 [in Ukrainian].

3. Judgment of May 5 Gaston Schul. (1982) case 15/81. Retrieved from: http://www.competitionlaw.cn/upload/temp_09060910426989.pdf

4. Nikolas Musys. (2005) Use pro spilni polityky Yevropeiskoho Soiuzu. [All about common policies of the European Union]. per. z anhl. Kyiv: «K.I.S.», 466 [in Ukrainian].

5. OCED Report. (2018) The Global environmental goods and services industry. Retrieved from: http://www.oecd.org/industry/ind/2090577.pdf 
6. Petrushenko Yu. M., Sadovyi V. O. \& Tarasenko S. V. (2009) Mizhnarodnyi dosvid formuvannia rynku ekolohobezpechnykh tovariv ta posluh. [International experience in shaping the market for environmentally friendly goods and services.]. Mekhanizm rehuliuvannia ekonomiky - The mechanism of economy regulation, 4, Vol. 2, 136141 [in Ukrainian].

7. Study on the Competitiveness of the EU eco-industry: Within the Framework Contract of Sectoral Competitiveness Studies - ENTR/06/054. (2009) Final Report. Part 1. Retrieved from: http://ec.europa.eu/DocsRoom/documents/1459/attachments/1/translations/en/renditions/native

8. Ernest\&Young Report for European Commission. (2006) Study on Eco-industry, its size, employment, perspectives and barriers to growth in an enlarged EU. Final report. Retrieved from: http://ec.europa.eu/environment/enveco/eco_industry/pdf/ecoindustry2006.pdf

9. The EU eco-industry in the world. (2009) Retrieved from: http://ec.europa.eu/environment/enveco

10. Study on the Competitiveness of the EU eco-industry. (2018) Brussels, 22 October, Ecorys, 216.

11. The environmental goods and services sector - a data collection handbook. (2019) Luxembourg: Office for Official Publications of the European Communities, 196.

12. EGSS production, \% of GDP, by type of activity (market, non market, ancillary), latest available year. (2019) Retrieved from: http://epp.eurostat.ec.europa.eu

13. The World of Organic Agriculture (2019). Retrieved from: https://www.organicworld.net/yearbook/yearbook-2019.html

Стаття надійшла до редакції 23.04.2020p. 